\title{
Early Recognition of Sepsis in the Emergency Department
}

\author{
Nycole D. Oliver*, DNP, RN, APRN, FNP-C, ACNPC-AG, CEN \\ Sparks Health System, 1001 Towson Ave. Fort Smith, AR 72901, University of South Alabama, 307 N. University \\ Blvd Mobile, AL 36688
}

\begin{abstract}
*Corresponding Author: Nycole D. Oliver, Sparks Health System, 1001 Towson Ave. Fort Smith, AR 72901, University of South Alabama, 307 N. University Blvd Mobile, AL 36688. Email: Nycole.Oliver@ yahoo.com
\end{abstract}

\section{Abstract}

Problem Statement: In the United States, over three-quarters of a million patients are hospitalized with sepsis each year, with a mortality rate of just over 200,000.

Purpose: Increase early sepsis recognition in the ED through utilization of early goal-directed therapy.

Methods: A retrospective chart review (pre- and post- screening tool implementation) research design was used. Subjects were chosen based on diagnosis codes placed by the emergency clinician. Inclusion criteria: patients over the age of 18 with suspected infection plus two or more systemic inflammatory response syndrome (SIRS) criteria: (a) heart rate greater than 90, (b) systolic blood pressure less than 90, (c) mean arterial pressure less than 65 , (d) temperature less than $96.8 \circ \mathrm{F}$ or above $100.5 \circ \mathrm{F}$, and (e) respiratory rate above 20.

Analysis: Paired sample t-tests and the Wilson Score Confidence Interval were used to evaluate data preand post-implementation.

Results: The data did not give sufficient evidence to conclude the screening tool decreased door to diagnosis time, door to lactate measurement, or increased the percentage of blood cultures obtained prior to antibiotic administration. The data did conclude a decrease in diagnosis to antibiotic administration.

Significance: A screening tool for early recognition of sepsis may lead to a decrease in door to antibiotic time.

Keywords: Sepsis, Screening Tool, Early Recognition, Emergency Department, Goal-Directed Therapy

Sepsis is a systemic inflammatory response typically triggered by an infection, and is associated with hypoperfusion, hypotension, and/or organ dysfunction (Hermans, Leffers, Jansen, Keulemans, \& Stassen, 2012; Burney et al., 2012). Sepsis accounts for over a half million emergency department (ED) visits each year (Hermans, et al., 2012). According to Hermans et al. (2012), one of the biggest advancements in sepsis treatment has been promotion of early goal-directed therapy (EGDT), a key component of which is early recognition in the ED.

In the United States, sepsis is in the top ten leading causes of death, with a mortality rate between forty to sixty percent (Burney et al., 2012). With over half a million annual ED visits for sepsis, the aforementioned mortality rate must be decreased. An interest by the corporate owner of a healthcare system has placed development of an early recognition protocol at the forefront of the ED director's agenda (Kelly Hill, personal communication, September 18, 2014).

In the United States, over three-quarters of a million patients are hospitalized with severe sepsis each year, with a mortality rate of just over 200,000 (Perman, Goyal, \&Gaieski, 2012). Medical costs related to sepsis are approximately $\$ 17$ billion annually (Seymour et al., 2012). From 2003 to 2007, the total number of sepsis cases increased by seventy-one percent, while the total hospital costs increased by fifty-seven percent (Lagu et al., 2012). Various cost analyses of initiating an early goaldirected sepsis protocol have been conducted, and have concluded a protocol is cost-effective in the long run, especially when patient mortality rates are considered (Jones, Troyer, \& Kline, 2011). 
To date, a major driver of early sepsis recognition is the Surviving Sepsis Campaign (SSC). The SSC was initiated in 2002, and is a partnership of the European Society of Intensive Care Medicine and the Society of Critical Care Medicine (Society of Critical Care Medicine, n.d.). Many organizations who have implemented the SSC have seen a drastic decrease in mortality related to sepsis.

\section{Clinical Question}

The clinical question identified using the elements of population/problem, intervention, comparison, and outcome (PICO) is:In an adult population in an ED setting, does implementation of an assessment tool for identifying sepsis patients increase early recognition of sepsis by decreasing door to diagnosis times, decreasing time of presentation to serum lactate measurement, decreasing diagnosis to antibiotic times, and increasingthe number of blood cultures being obtained before antibiotic administration?

\section{REVIEW OF LITERATURE}

The University of South Alabama'sBiomedical Library, MEDLINE, and the Cumulative Index to Nursing and Allied Health Literature (CINAHL) databases were utilized for search of the literature. Terms used for exploration included sepsis, early recognition of sepsis, sepsis and emergency department, sepsis protocol and emergency department, early recognition of sepsis and emergency department, and sepsis and early goal directed therapy. Search dates were limited to the last 5 years, and further refinement to only articles with full-text availability was performed.

After refinement of only full-text articles within the last 5 years, there were 3,512 hits while searching sepsis, 15 hits with early recognition of sepsis,145 with sepsis and emergency department, 6 with sepsis protocol and emergency department, 6 with early recognition of sepsis and emergency department, and 29 with sepsis and early goal directed therapy. Each abstract was reviewed by the DNP student to determine relevancy to the clinical question. Fifteen studies were chosen for the literature summary table (see Appendices A-C), and each article was graded and ranked.

Of the studies, three were ranked a level I (evidence from at least one well-designed randomized controlled trial), six were a level II2 (data from well-designed cohort or casecontrol analytic studies, from more than one center or research groupif at all possible), and six were a level II-3 (comparisons between times or places with or without the intervention: results from uncontrolled studies). For grading, ten were graded 1C (strong; can apply to most patients in most circumstances), two were graded 2A (intermediate-strength; best action may differ depending on circumstances or patient or societal values), and two were graded 2B (weak; alternate approaches likely to be better for some patients under certain circumstances).

The literature supplies different tactics to approach early recognition of sepsis in the ED; however, the research employs the same principle: a standardized approach and early recognition protocol must be in place to recognize, diagnose, and treat sepsis in the ED in a timely manner in order to increase outcomes for the patient and decrease length of stay and subsequent hospital costs. Seven of the fifteen studies included in the literature review recommend employing a triage screening tool and/or sepsis protocol in the ED to facilitate early recognition so the patient can receive treatment sooner, and increase the chances of survival. The studies employing a screening tool and/or ED sepsis protocol for EGDT showed a significant reduction in the time of diagnosis to antibiotic time and had a subsequent decrease in mortality rates (see Appendix A).

\section{Project Methodology}

\section{Subjects}

Subjects were chosen based on diagnosis codes placed by the emergency clinician. Participants included ED patients at or over the age of 18 with suspected signs and symptoms of sepsis (described with inclusion criteria later). Participants were of different ages, various racial backgrounds, and from both genders. Inclusion criteria were patients with suspected infection such as pneumonia, skin infection, urinary tract infection, meningitis, abdominal infection, bone or joint infection, indwelling device/line, flu/viral/fungal illness plus two or more systemic inflammatory response syndrome (SIRS) criteria: (a) heart rate greater than 90, (b) systolic blood pressure less than 90, (c) mean arterial pressure less than 65 , (d) temperature less than $96.8^{\circ} \mathrm{F}$ or above $100.5 \circ \mathrm{F}$, and (e) respiratory rate above 20 (Appendix D). Exclusion criteria were patients who did not meet the criteria for sepsis according to a modified version of the Surviving Sepsis Campaign's screening tool (Surviving Sepsis, 2013) (Appendix D). 


\section{Setting}

The practice setting in which the project was implemented was a rural hospital ED in Fort Smith, Arkansas. The institution had over 154,000 patient interactions in 2011, and is growing each year (Sparks Health System, 2014). The hospital is licensed for 492 beds; the ED has 33 with the potential for 10 additional overflow beds. The ED treated over 70,000 patients in 2014. During a 12-hour shift, the ED is preferably staffed with: twelve Registered Nurses (RNs)/Licensed Practical Nurses (LPNs), two Unit Secretaries, three ED Technicians, three/four physicians/Nurse Practitioners, and twoTriage Technicians, along with subsidary staff (J. W. Kennon, personal communication, January 17, 2015).

\section{Tools}

A modification of the Surviving Sepsis Campaign's data collection tool (Appendix E) best evaluated effectiveness for the student's project (Surviving Sepsis Campaign, n.d). The tool has been utilized by numerous hospitals as part of the Surviving Sepsis Campaign bundles and has been proven to be a valid and reliable tool in measuring each step of the process. The modified tool measured whether the patient met criteria for sepsis based on the aforementioned screening tool (Appendix D), the date and time of presentation, admission category, serum lactate measurement and time, blood culture collection and time, antibiotic administration and time, and hospital discharge date and time.

\section{Intervention and Data Collection}

To implement the project, the student identified a phenomenon of interest, performed a needs assessment, completed a literature review, established aims and outcomes for the project, provided a QI, EBP, and nursing theory model for basis of the project, and described project methodology. First, the student set up a measuring system to gather information in a 3 month retrospective chart review to determine the success of identifying patients with sepsis and determine the door to diagnosis time, the amount of time it took for a sepsis diagnosis before antibiotic administration, the time of lactate measurement, and the percentage of blood cultures obtained before antibiotic administration. Second, the student implemented a screening tool for the triage nurse to utilize to identify potential sepsis patients (with buy-in from the ED administrative staff and physicians). A process map of the screening tool is provided for review
(Appendix F). Nurses, ED physicians, and ED technicians and secretaries were educated on the new screening process in shift change reports and with handouts so they were aware of the new process. Next, the student had the ED nurses utilize the new sepsis screening tool to prospectively flag sepsis patients and measured any improvement in recognition of the patient with sepsis and subsequently decrease door to diagnosis times, decrease the time from presentation to serum lactate measurement, decrease diagnosis to antibiotic times, and increase blood culture collection prior to antibiotic administration. The screening tool was utilized for a period of two months. Each patient was given an information sheet outlining the project and informing them what would be done with the information obtained during the study (Appendix G)

Next, the student did a chart review for the 2month period of screening tool implementation to determine if the screening tool was effective in decreasing door to diagnosis times, decreasing the time from presentation to serum lactate measurement, decreasing diagnosis to antibiotic times, and increasing blood culture collection prior to antibiotic administration.

\section{Analysis/Evaluation Plan}

The student partnered with the information technology department in the institution to analyze data for the project by utilizing the paper data collection tool (Appendix E). Outcomes performance measures to determine the project's effectiveness include (a) reducing door to diagnosis times, (b) decreasing time from presentation to serum lactate measurement, (c) decreasing diagnosis to antibiotic times, and (d) increasing the number of blood cultures obtained before antibiotic administration. The student did a retrospective pre/post project implementation chart review to determine the amount of time it took for a lactate measurement and sepsis diagnosis before the screening tool compared to after the screening tool, as well as the time from diagnosis to antibiotic administration before and after implementation. The student additionally calculated the percentage of blood cultures obtained prior to initial antibiotic administration prior to and after project implementation. The overall goal of the project was to increase early sepsis recognition in the ED through utilization of early goaldirected therapy.

Paired sample t-tests were used to evaluate whether there was a reduction in door to sepsis diagnosis, door to lactate, and diagnosis to 
antibiotic times pre- and post- implementation. The Wilson Score Confidence Interval was used to compare the percentage of blood cultures collected before antibiotic administration preand post- implementation.

\section{RESULTS AND DISCUSSION}

\section{Results}

The study included 63 patients presenting to the ED before screening tool implementation, and 23 patients after implementation. There were no statistically significant differences in patient

Table1. Significance of Door to Sepsis Diagnosis

\begin{tabular}{|c|c|c|c|c|c|c|c|c|c|}
\hline \multicolumn{3}{|c|}{ T TEST: Equal Variances } & \multirow[b]{2}{*}{$d f$} & \multirow{2}{*}{$\frac{\text { Alpha }}{p \text {-value }}$} & \multirow{2}{*}{$\frac{0.05}{t \text {-crit }}$} & \multirow[b]{2}{*}{ lower } & \multirow[b]{2}{*}{ upper } & \multirow[b]{2}{*}{ sig } & \multirow[b]{2}{*}{ effect $r$} \\
\hline & std err & $t$-stat & & & & & & & \\
\hline \multicolumn{10}{|l|}{ One } \\
\hline Tail & 13.90085 & 0.744907 & 82 & 0.229229 & 1.663649 & & & no & 0.081984 \\
\hline \multicolumn{10}{|l|}{ Two } \\
\hline Tail & 13.90085 & 0.744907 & 82 & 0.458458 & 1.989319 & 17.2984 & 38.00806 & no & 0.081984 \\
\hline \multicolumn{3}{|c|}{ T TEST: Unequal Variances } & & Alpha & 0.05 & & & & \\
\hline & std err & $t$-stat & $d f$ & p-value & $t$-crit & lower & upper & sig & effect $r$ \\
\hline \multicolumn{10}{|l|}{ One } \\
\hline Tail & 11.93586 & 0.86754 & 51.13845 & 0.194849 & 1.675285 & & & no & 0.120432 \\
\hline Two & & & & & & - & & & \\
\hline Tail & 11.93586 & 0.86754 & 51.13845 & 0.389699 & 2.007584 & 13.6074 & 34.31708 & no & 0.120432 \\
\hline
\end{tabular}

Table2. Significance of Door to Lactate

\begin{tabular}{|c|c|c|c|c|c|c|c|c|c|}
\hline \multicolumn{3}{|c|}{ T TEST: Equal Variances } & \multirow[b]{2}{*}{$d f$} & \multirow{2}{*}{$\begin{array}{l}\text { Alpha } \\
p \text {-value }\end{array}$} & \multirow{2}{*}{$\frac{0.05}{t \text {-crit }}$} & \multirow[b]{2}{*}{ lower } & \multirow[b]{2}{*}{ upper } & \multirow[b]{2}{*}{ sig } & \multirow[b]{2}{*}{ effect $r$} \\
\hline & std err & $t$-stat & & & & & & & \\
\hline One & & & & & & & & & \\
\hline Tail & 54.36254 & 0.906076 & 82 & 0.183775 & 1.663649 & & & no & 0.099562 \\
\hline Two & & & & & & & & & \\
\hline Tail & 54.36254 & 0.906076 & 82 & 0.36755 & 1.989319 & 157.401 & 58.88781 & no & 0.099562 \\
\hline T TEST & Unequal V & riances & & Alpha & 0.05 & & & & \\
\hline & std err & $t$-stat & $d f$ & $p$-value & $t$-crit & lower & upper & sig & effect $r$ \\
\hline One & & & & & & & & & \\
\hline Tail & 71.85305 & 0.685519 & 25.2964 & 0.249626 & 1.708141 & & & no & 0.135049 \\
\hline Two & & & & & & & & & \\
\hline Tail & 71.85305 & 0.685519 & 25.2964 & 0.499251 & 2.059539 & 197.241 & 98.72753 & no & 0.135049 \\
\hline
\end{tabular}

Table3. Significance of Diagnosis to Antibiotic Administration

\begin{tabular}{|c|c|c|c|c|c|c|c|c|c|}
\hline T TES & Equal Vari & nces & & Alpha & 0.05 & & & & \\
\hline & std err & $t$-stat & $d f$ & $p$-value & $t$-crit & lower & upper & sig & effect $r$ \\
\hline One & & & & & & & & & \\
\hline Tail & 39.44828 & 1.572645 & 82 & 0.059826 & 1.663649 & & & no & 0.171108 \\
\hline Two & & & & & & - & & & \\
\hline Tail & 39.44828 & 1.572645 & 82 & 0.119652 & 1.989319 & 16.4371 & 140.5133 & no & 0.171108 \\
\hline T TES & Unequal V & riances & & Alpha & 0.05 & & & & \\
\hline & std err & $t$-stat & $d f$ & $p$-value & t-crit & lower & upper & sig & effect $r$ \\
\hline One & & & & & & & & & \\
\hline Tail & 29.39412 & 2.110562 & 72.2102 & 0.019137 & 1.666294 & & & yes & 0.241046 \\
\hline Two & & & & & & - & & & \\
\hline Tail & 29.39412 & 2.110562 & 72.2102 & 0.038274 & 1.993464 & 3.44201 & 120.6342 & yes & 0.241046 \\
\hline
\end{tabular}

Table4. Percentage of Blood Culture Prior to Antibiotic Administration

Alternative Hypothesis: $\mathrm{p} 1 \mathrm{not}=\mathrm{p} 2$

Pooled proportion: 0.7619048

Test Statistic, z: 0.4439 


\begin{tabular}{|l|}
\hline Critical z: \pm 1.9600 \\
\hline P-Value:0.6571 \\
\hline $95 \%$ Confidence interval: \\
\hline$-0.1663049<\mathrm{p} 1-\mathrm{p} 2<0.2601465$ \\
\hline We cannot conclude that the two proportions are different at 0.05 significance level \\
\hline
\end{tabular}

The literature concludes sepsis outcomes can be enhanced though early recognition. The factors in this project have been studied extensively, and although the particular project did not correlate with the literature completely, with more time and data, the outcomes would likely match up.

\section{Discussion}

The quality of care for sepsis patients can be increased by a relatively simple and inexpensive method such as the proposed screening tool. To further progress care for sepsis patients and improve early recognition of patients with sepsis in the ED setting, additional improvement activities and compliance with sepsis protocols put into action are required. An electronic screening tool would perhaps be more userfriendly and convenient for the nurses, since they had to remember to pull the paper screening tool each time a patient came in.

An early screening protocol utilizing the sepsis screening tool would also be beneficial. After speaking with the ED nurses in the project implementation institution, suggestions were made to make the paper tool an electronic version and tie it into the electronic health record the hospital uses. The nurses stated if the screening tool was in the computer and made a "required" point of the triage, there would be more compliance and accuracy with the tool.

\section{LIMITATIONS}

The study is limited in being an uncontrolled study in a single hospital. The short time frame for screening tool implementation also limits the potential. Only 13 screening tool were utilized during the two-month period of implementation, despite the fact there were 23 sepsis patients during that period. A paper screening tool may be viewed as an inconvenience for triage nurses, thus decreasing compliance rates. According to the information technology department at the hospital where the project took place, the components of the screening tool can be incorporated into the electronic chart to prospectively flag each patient meeting the criteria for sepsis, perhaps as an option in the future.

Since only providers can order antibiotics, the responsibility of that component lies with the provider. The screening tool, however, has the potential to empower the nurses to question about the need for antibiotic therapy earlier.

\section{CONCLUSIONS/SIGNIFICANCE TO AdVANCE NurSing Practice}

A screening tool for early recognition of sepsis may lead to a decrease in door to antibiotic time. Sepsis is a life-threatening condition that impacts thousands of people each year. Evidence concludes early and assertive treatment in the ED can make a difference in patient outcomes (Vanzant \& Schmelzer, 2011). The student's project will make a difference in population outcomes by raising awareness of the condition early so treatment can begin in a timely manner, thus decreasing mortality rates from sepsis. The project could also impact the way care is implemented by increasing awareness of the signs and symptoms of sepsis and lessen the amount of time before action is taken.

\section{ACKNOWLEDGEMENTS}

I would like to thank the Institutional Review Board, nurses, ED providers, ED techs, ED unit assistants, and the rest of the ED staff from Sparks Health System for including the patients in the sepsis screening tool process, and for ensuring safe and effective care for sepsis patients presenting through the ED of the aforementioned institution. I would also like to thank Steward Huang, PhD for his help with statistical analysis of the project.

\section{REFERENCES}

[1] Berger, T., Green, J., Horeczko, T., Hagar, Y., Garg, N., Suarez, A., ... Shapiro, N. (2013). Shock index and early recognition of sepsis in the emergency department: Pilot study. Western Journal of Emergency Medicine, 14(2), 168174. doi:10.5811.westjem.2012.8.11546

[2] Burney, M., Underwood, J., McEvoy, S., Nelson, G., Dzierba, A., Kauari, V., \& Chong, D. (2012). Early detection and treatment of severe sepsis in the emergency department: Identifying barriers to implementation of a protocol-based approach. Journal of Emergency Nursing, 38(6), 512-517. doi:10.1016/ j.jen. 2011.08.011

[3] Calle, P., Cerro, L., Valencia, J., \& Fabian, J. (2012). Usefulness of severity scores in patients with suspected infection in the emergency department: A systematic review. The Journal of Emergency Medicine, 42(4), 379-391. doi:10.1016/j/jemermed.2011.03.033 
[4] DiCenso, A., Guyatt, G., \&Ciliska, D. (2005). Evidence-based nursing: A guide to clinical practice (pp 166 \& 519). St. Louis, MO: Mosby

[5] Hermans, M. A., Leffers, P., Jansen, L. M., Keulemans, Y. C., \& Stassen, P. M. (2012). The value of the Mortality in Emergency Department Sepsis (MEDS) score, $\mathrm{C}$ reactive protein and lactate in predicting 28-day mortality of sepsis in a Dutch emergency department. Emergency Medicine Journal, 29(4), 295-300. doi:10.1136/emj.2010.109090

[6] Jones, A. E., Troyer, J. L., \& Kline, J. A. (2011). Cost-effectiveness of an emergency department based early sepsis resuscitation protocol. Critical Care Medicine, 39(6), 13061312. doi:10.1097/CCM.0b01 3e31821201be

[7] Judd, W. R., Stephens, D. M., \& Kennedy, C. A. (2014). Clinical and economic impact of a quality improvement initiative to enhance early recognition and treatment of sepsis. Annals of Pharmacotherapy, 48(10), 1269-1275. doi:10.1177/1060028014541792

[8] Lagu, T. Rothberg, M. B., Shieh, M., Pekow, P. S., Steingrub, J. S., \&Lindenauer, P. K. (2012). Hospitalizations, costs, and outcomes of severe sepsis in the United States 2003 to 2007. Critical Care Medicine, 40(3), 754-761. doi:10.1097/ccm.0b013e318232db65

[9] Kent, N., \& Fields, W. (2012). Early recognition of sepsis in the emergency department: An evidence-based project. Journal of Emergency Nursing, 38(2), 139-143. doi:10.1016/j.jen.2010.07.022

[10] Nguyen, H. B., Ginkel, C. V., Batech, M., Banta, J., \& Corbett, S. W. (2012). Comparison of Predisposition, Insult/Infection, Response, and Organ dysfunction, Acute Physiology And Chronic Health Evaluation II, and Mortality in Emergency Department Sepsis in patients meeting criteria for early goal-directed therapy and the severe sepsis resuscitation bundle. Journal of Critical Care, 27(4), 362-369. doi:10.1016/j.jcrc.2011.08.013

[11] Patocka, C., Turner, J., Xue, X., \& Segal, E. (2014). Evaluation of an emergency department triage screening tool for suspected severe sepsis and septic shock. Journal for Healthcare Quality, 36(1), 52-61. doi:10.1111/jhq.12055

[12] Perman, S. M., Goyal, M., \&Gaieski, D. F. (2012). Initial emergency department diagnosis and management of adult patients with severe sepsis and septic shock. Scandinavian Journal of Trauma, Resuscitation, and Emergency Medicine, 20(41), 1-11. doi:10.1186/17577241-20-41

[13] Puskarich, M. A., Illich, B. M., \& Jones, A. E. (2014). Prognosis of emergency department patients with suspected infection and intermediate lactate levels: A systematic review. Journal of Critical Care, 29(3), 334339. doi:10.1016/j.jcrc.2013.12.017
[14] Schaub, N., Boldanova, T., Noveanu, M., Arenja, N., Hermann, H., Twerenbold, R., ... Mueller, C. (2014). Incremental value of multiplex real-time PCR for the early diagnosis of sepsis in the emergency department. Swiss Medical Weekly, 144(11), 1-10. doi:10.4414/smw.2014.13911

[15] Seymour, C. W., Rea, T. D., Kahn, J. M., Walkey, A. J., Yealy, D. M., \& Angus, D. C. (2012). Severe sepsis in pre-hospital emergency care: Analysis of incidence, care, and outcome. American Journal of Respiratory and Critical Care Medicine, 186(12), 1264-1271. doi:10.1164/rccm.201204-07130C

[16] Society of Critical Care Medicine. (n.d.). About the Surviving Sepsis Campaign. Retrieved from http://www.survivingsepsis.org/AboutSSC/Pages/default.aspx

[17] Sparks Health System. (2014). Mission, vision, and values. Retrieved from http:// www. sparks health.com/ about/mission

[18] Surviving Sepsis Campaign (n.d.) Severe sepsis chart review data collection tool for educational purposes. Retrieved from http:// www.survivingsepsis.org/SiteCollectionDocum ents/Data-Collection-Surviving-Sepsis.pdf

[19] Surviving Sepsis Campaign (2013). Evaluation of severe sepsis screening tool. Retrieved from http://www.survivingsepsis.org/SiteCollection Documents/ScreeningTool.pdf

[20] Tipler, P. S., Pamplin, J., Mysliwiec, V., Anderson, A., \& Mount, C. A. (2013). Use of a protocolized approach to the management of sepsis can improve time to first dose of antibiotics. Journal of Critical Care, 28(2), 148-151. doi:10.1016/j.jcrc.2012.08.021

[21] Tromp, M., Hulscher, M., Bleeker-Rovers, C. P., Peters, L., van den Berg, D. T., Borm, G. F., ... Pickkers, P. (2010). The role of nurses in the recognition and treatment of patients with sepsis in the emergency department: A prospective before-and-after intervention study. International Journal of Nursing Studies, 47(12), 1464-1473. doi:10.1016/ j.ijnurstu. 2010.04.007

[22] Turi, S. K., \& Von Ah, D. (2013). Implementation of early goal-directed therapy for septic patients in the emergency department: A review of the literature. Journal of Emergency Nursing, 39(1), 13-19. doi:10. 1016/j/jen.2011.06.006

[23] Vanzant, A. M., \&Schmelzer, M. (2011). Detecting and treating sepsis in the emergency department. Journal of Emergency Nursing, 37(1), 47-54. doi:10.1016/j.jen.2010.06.020

[24] Zhao, Y., Li, C., \& Jia, Y. (2013). Evaluation of the Mortality in Emergency Sepsis score combined with procalcitonin in septic patients. American Journal of Emergency Medicine, 31(7), 1086-1091. doi:10.1016/j.ajem. 2013. 04.008 


\section{APPENDIX A}

Literature Review Summary Table

\begin{tabular}{|c|c|c|c|c|c|c|}
\hline Year & $\begin{array}{c}\text { Author } \\
\text { Title } \\
\text { Journal }\end{array}$ & Purpose & Design/Sample & $\begin{array}{c}\text { Results/ } \\
\text { Recommendations }\end{array}$ & Limitations & $\begin{array}{l}\text { Level/ } \\
\text { Grade }\end{array}$ \\
\hline 2013 & $\begin{array}{l}\text { Berger, T., } \\
\text { Green, J., } \\
\text { Horeczko, } \\
\text { T., Hagar, } \\
\text { Y., Garg, N., } \\
\text { Suarez, A., } \\
\text {... Shapiro, } \\
\text { N. } \\
\text { Shock index } \\
\text { and early } \\
\text { recognition } \\
\text { of sepsis in } \\
\text { the } \\
\text { emergency } \\
\text { department: } \\
\text { Pilot study. } \\
\text { Western } \\
\text { Journal of } \\
\text { Emergency } \\
\text { Medicine }\end{array}$ & $\begin{array}{l}\text { To compare } \\
\text { the ability of } \\
\text { shock index } \\
\text { (SI), } \\
\text { individual } \\
\text { vital signs, } \\
\text { and the } \\
\text { systemic } \\
\text { inflammatory } \\
\text { response } \\
\text { syndrome } \\
\text { (SIRS) criteria } \\
\text { to predict the } \\
\text { primary } \\
\text { outcome of } \\
\text { hyperlactatem } \\
\text { ia (serum } \\
\text { lactate } \geq 4.0 \\
\text { mmol/L) as a } \\
\text { surrogate for } \\
\text { disease } \\
\text { severity, and } \\
\text { the secondary } \\
\text { outcome of } \\
\text { 28-day } \\
\text { mortality. }\end{array}$ & Cohort study & $\begin{array}{l}\text { SI performed as } \\
\text { well as SIRS in } \\
\text { negative predictive } \\
\text { value and was the } \\
\text { most sensitive } \\
\text { screening test for } \\
\text { hyperlactatemia and } \\
\text { 28-day mortality. } \\
\text { SI was the most } \\
\text { specific predictor of } \\
\text { both outcomes. }\end{array}$ & $\begin{array}{l}\text { Data were } \\
\text { collected via } \\
\text { retrospective } \\
\text { computerized } \\
\text { chart review. } \\
\text { Concurrent } \\
\text { medication } \\
\text { information } \\
\text { was not } \\
\text { collected, and } \\
\text { any potential } \\
\text { influence of } \\
\text { meds on vital } \\
\text { signs was not } \\
\text { controlled. } \\
\text { The cohort } \\
\text { was elderly, } \\
\text { with a mean } \\
\text { age of } 73 \\
\text { years. }\end{array}$ & $\begin{array}{l}\text { II-2 } \\
1 \mathrm{C}\end{array}$ \\
\hline 2012 & $\begin{array}{l}\text { Calle, P., } \\
\text { Cerro, L., } \\
\text { Valencia, J., } \\
\text { \& Fabian, J. } \\
\text { Usefulness } \\
\text { of severity } \\
\text { scores in } \\
\text { patients with } \\
\text { suspected } \\
\text { infection in } \\
\text { the } \\
\text { emergency } \\
\text { department: } \\
\text { A systematic } \\
\text { review. } \\
\text { The Journal } \\
\text { of } \\
\text { Emergency } \\
\text { Medicine }\end{array}$ & $\begin{array}{l}\text { To establish } \\
\text { the accuracy } \\
\text { of score } \\
\text { systems in the } \\
\text { prediction of } \\
\text { mortality in } \\
\text { patients with } \\
\text { suspected } \\
\text { infection in } \\
\text { hospital } \\
\text { settings } \\
\text { compared to } \\
\text { the ICU. }\end{array}$ & $\begin{array}{l}\text { Systematic } \\
\text { review }\end{array}$ & $\begin{array}{l}21 \text { studies were } \\
\text { included, } 19 \text { of } \\
\text { which were carried } \\
\text { out in the ED. } \\
\text { The reviewed } \\
\text { literature did not } \\
\text { provide enough } \\
\text { evidence to assess } \\
\text { the accuracy of the } \\
\text { prognostic models } \\
\text { in patients with } \\
\text { suspected infection } \\
\text { admitted to the ED } \\
\text { and hospital ward. } \\
\text { Some reports } \\
\text { suggested better } \\
\text { accuracy with new } \\
\text { scores like the } \\
\text { MEDS, but the } \\
\text { results are not } \\
\text { consistent. }\end{array}$ & $\begin{array}{l}\text { Only the } \\
\text { PubMed } \\
\text { database was } \\
\text { utilized. } \\
\text { Only articles } \\
\text { in the English } \\
\text { language } \\
\text { were utilized. }\end{array}$ & $\begin{array}{l}\mathrm{I} \\
2 \mathrm{~B}\end{array}$ \\
\hline 2012 & $\begin{array}{l}\text { Hermans, M. } \\
\text { A., Leffers, } \\
\text { P., Jansen, L. } \\
\text { M., } \\
\text { Keulemans, } \\
\text { Y. C., \& } \\
\text { Stassen, P. } \\
\text { M. }\end{array}$ & $\begin{array}{l}\text { To validate } \\
\text { the Mortality } \\
\text { in Emergency } \\
\text { Department } \\
\text { Sepsis } \\
\text { (MEDS) score } \\
\text { as a predictor } \\
\text { of } 28 \text {-day }\end{array}$ & Cohort Study & $\begin{array}{l}\text { The MEDS score } \\
\text { was found to be a } \\
\text { good risk } \\
\text { stratification tool in } \\
\text { ED patients with } \\
\text { sepsis who are } \\
\text { treated by an } \\
\text { internist. }\end{array}$ & $\begin{array}{l}\text { The notes of } \\
\text { the attending } \\
\text { doctors were } \\
\text { depended on } \\
\text { for the } \\
\text { necessary } \\
\text { info for the } \\
\text { study. }\end{array}$ & $\begin{array}{l}\text { II-2 } \\
1 \mathrm{C}\end{array}$ \\
\hline
\end{tabular}




\begin{tabular}{|c|c|c|c|c|c|c|}
\hline Year & $\begin{array}{c}\text { Author } \\
\text { Title } \\
\text { Journal }\end{array}$ & Purpose & Design/Sample & $\begin{array}{c}\text { Results/ } \\
\text { Recommendations }\end{array}$ & Limitations & $\begin{array}{l}\text { Level/ } \\
\text { Grade }\end{array}$ \\
\hline & $\begin{array}{l}\text { The value of } \\
\text { the Mortality } \\
\text { in } \\
\text { Emergency } \\
\text { Department } \\
\text { Sepsis } \\
\text { (MEDS) } \\
\text { score, C } \\
\text { reactive } \\
\text { protein and } \\
\text { lactate in } \\
\text { predicting } \\
\text { 28-day } \\
\text { mortality of } \\
\text { sepsis in a } \\
\text { Dutch } \\
\text { emergency } \\
\text { department. } \\
\text { Emergency } \\
\text { Medicine } \\
\text { Journal }\end{array}$ & $\begin{array}{l}\text { mortality rate } \\
\text { in ED patients } \\
\text { with sepsis in } \\
\text { the } \\
\text { Netherlands. } \\
\text { To compare } \\
\text { the MEDS } \\
\text { score } \\
\text { performance } \\
\text { to C reactive } \\
\text { protein and } \\
\text { lactate. }\end{array}$ & & $\begin{array}{l}\text { The MEDS score is } \\
\text { a good predictor of } \\
\text { mortality and is } \\
\text { particularly feasible } \\
\text { in the ED setting, as } \\
\text { all items are readily } \\
\text { available. } \\
\text { Discriminative } \\
\text { ability of CRP was } \\
\text { poor. } \\
\text { Discriminative } \\
\text { ability of lactate } \\
\text { level was fair. } \\
\text { MEDS score could } \\
\text { be improved by } \\
\text { combing with } \\
\text { lactate levels. }\end{array}$ & $\begin{array}{l}\text { Judgment } \\
\text { about life } \\
\text { expectancy } \\
\text { was made } \\
\text { retrospectivel } \\
\text { y based on } \\
\text { the patient } \\
\text { records. } \\
\text { The death } \\
\text { rate was } \\
\text { dependent on } \\
\text { the severity } \\
\text { of the disease } \\
\text { at the } \\
\text { moment of } \\
\text { presentation } \\
\text { to the ED and } \\
\text { on decisions } \\
\text { about } \\
\text { treatment. } \\
\text { The influence } \\
\text { of sepsis on } \\
\text { mortality may } \\
\text { extend further } \\
\text { than the first } \\
28 \text { days. }\end{array}$ & \\
\hline 2014 & $\begin{array}{l}\text { Judd, W. R., } \\
\text { Stephens, D. } \\
\text { M., } \\
\text { \&Kennedy, } \\
\text { C. A. } \\
\text { Clinical and } \\
\text { economic } \\
\text { impact of a } \\
\text { quality } \\
\text { improvement } \\
\text { initiative to } \\
\text { enhance } \\
\text { early } \\
\text { recognition } \\
\text { and } \\
\text { treatment of } \\
\text { sepsis } \\
\text { Annals of } \\
\text { Pharmacothe } \\
\text { rapy }\end{array}$ & $\begin{array}{l}\text { To evaluate } \\
\text { the clinical } \\
\text { and economic } \\
\text { impact of a } \\
\text { sepsis quality } \\
\text { improvement } \\
\text { initiative to } \\
\text { improve early } \\
\text { recognition } \\
\text { and treatment } \\
\text { of sepsis. }\end{array}$ & $\begin{array}{l}\text { Retrospective } \\
\text { observational } \\
\text { study }\end{array}$ & $\begin{array}{l}\text { Nonsignificant } \\
\text { decreases in LOS } \\
\text { and in-hospital } \\
\text { mortality were } \\
\text { observed in patients } \\
\text { with sepsis. } \\
\text { Early recognition } \\
\text { and treatment } \\
\text { contributed to } \\
\text { significant } \\
\text { reductions in ICU } \\
\text { LOS and total cost } \\
\text { per case. } \\
\text { Strategies to } \\
\text { improve early } \\
\text { recognition and } \\
\text { treatment of sepsis, } \\
\text { including routine } \\
\text { use of an electronic } \\
\text { sepsis screening } \\
\text { tool and } \\
\text { implementation of a } \\
\text { first dose STAT } \\
\text { antibiotic policy, } \\
\text { contributed to } \\
\text { significant } \\
\text { reductions in ICU } \\
\text { LOS and cost per } \\
\text { case. }\end{array}$ & $\begin{array}{l}\text { The } \\
\text { retrospective } \\
\text { quality of the } \\
\text { study can } \\
\text { cause } \\
\text { significant } \\
\text { limitations. } \\
\text { Septic } \\
\text { patients were } \\
\text { identified } \\
\text { using DRGs, } \\
\text { which rely on } \\
\text { the accuracy } \\
\text { of the } \\
\text { individual } \\
\text { coder and } \\
\text { require } \\
\text { accurate } \\
\text { documentatio } \\
\text { n to } \\
\text { determine the } \\
\text { principal } \\
\text { diagnosis. }\end{array}$ & $\begin{array}{l}\mathrm{II}-3 \\
1 \mathrm{C}\end{array}$ \\
\hline
\end{tabular}




\begin{tabular}{|c|c|c|c|c|c|c|}
\hline Year & $\begin{array}{c}\text { Author } \\
\text { Title } \\
\text { Journal }\end{array}$ & Purpose & Design/Sample & $\begin{array}{c}\text { Results/ } \\
\text { Recommendations }\end{array}$ & Limitations & $\begin{array}{l}\text { Level/ } \\
\text { Grade }\end{array}$ \\
\hline 2012 & $\begin{array}{l}\text { Kent, N., \& } \\
\text { Fields, W. } \\
\text { Early } \\
\text { recognition } \\
\text { of sepsis in } \\
\text { the } \\
\text { emergency } \\
\text { department: } \\
\text { An evidence- } \\
\text { based project } \\
\text { Journal of } \\
\text { Emergency } \\
\text { Nursing }\end{array}$ & $\begin{array}{l}\text { To implement } \\
\text { a sepsis } \\
\text { screening } \\
\text { measure for } \\
\text { improving the } \\
\text { identification, } \\
\text { communicatio } \\
\mathrm{n}, \text {, and } \\
\text { treatment of } \\
\text { patients with } \\
\text { sepsis. }\end{array}$ & $\begin{array}{l}\text { Evidence-based } \\
\text { project }\end{array}$ & $\begin{array}{l}\text { Utilization of a } \\
\text { sepsis screening } \\
\text { measure increases } \\
\text { recognition of a } \\
\text { small number of } \\
\text { patients who } \\
\text { present to the ED } \\
\text { with severe sepsis. } \\
\text { Hospitals should } \\
\text { benefit from } \\
\text { utilizing a nurse- } \\
\text { based screening } \\
\text { measure to } \\
\text { recognize severe } \\
\text { sepsis, thus guiding } \\
\text { nursing and medical } \\
\text { care. }\end{array}$ & $\begin{array}{l}\text { This project } \\
\text { is limited in } \\
\text { that it was } \\
\text { only } \\
\text { implemented } \\
\text { at one } \\
\text { hospital for a } \\
\text { short period } \\
\text { of time. } \\
\text { There were a } \\
\text { low number } \\
\text { of patients in } \\
\text { the study who } \\
\text { actually } \\
\text { screened } \\
\text { positive for } \\
\text { severe sepsis, } \\
\text { further } \\
\text { limiting the } \\
\text { study. }\end{array}$ & $\begin{array}{l}\text { II-3 } \\
\text { 2B }\end{array}$ \\
\hline 2012 & $\begin{array}{l}\text { Nguyen, H. } \\
\text { B., Ginkel, } \\
\text { C. V., } \\
\text { Batech, M., } \\
\text { Banta, J., \& } \\
\text { Corbett, S. } \\
\text { W. } \\
\text { Comparison } \\
\text { of } \\
\text { Predispositio } \\
\text { n, } \\
\text { Insult/Infecti } \\
\text { on, } \\
\text { Response, } \\
\text { and Organ } \\
\text { dysfunction, } \\
\text { Acute } \\
\text { Physiology } \\
\text { And Chronic } \\
\text { Health } \\
\text { Evaluation } \\
\text { II, and } \\
\text { Mortality in } \\
\text { Emergency } \\
\text { Department } \\
\text { Sepsis in } \\
\text { patients } \\
\text { meeting } \\
\text { criteria for } \\
\text { early goal- } \\
\text { directed } \\
\text { therapy and } \\
\text { the severe } \\
\text { sepsis } \\
\text { resuscitation } \\
\text { bundle. }\end{array}$ & $\begin{array}{l}\text { To examine } \\
\text { the } \\
\text { performance } \\
\text { of the } \\
\text { Predisposition } \\
\text { Insult/Infectio } \\
\text { n, Response, } \\
\text { and Organ } \\
\text { dysfunction } \\
\text { (PIRO) model } \\
\text { compared } \\
\text { with the } \\
\text { Acute } \\
\text { Physiology } \\
\text { and Chronic } \\
\text { Health } \\
\text { Evaluation } \\
\text { (APACHE) II } \\
\text { and Mortality } \\
\text { in Emergency } \\
\text { Department } \\
\text { Sepsis } \\
\text { (MEDS) } \\
\text { scoring } \\
\text { systems in } \\
\text { predicting in- } \\
\text { hospital } \\
\text { mortality for } \\
\text { patients } \\
\text { presenting to } \\
\text { the emergency } \\
\text { department } \\
\text { (ED) with } \\
\text { severe sepsis } \\
\text { or septic } \\
\text { shock. }\end{array}$ & Cohort study & $\begin{array}{l}\text { In this patient } \\
\text { cohort, PIRO } \\
\text { performed equally } \\
\text { well when } \\
\text { compared with } \\
\text { APACHE II and } \\
\text { surpassed MEDS in } \\
\text { discriminating } \\
\text { survivors from } \\
\text { nonsurvivors. } \\
\text { PIRO was less } \\
\text { time- consuming to } \\
\text { compute compared } \\
\text { with APACHE II } \\
\text { and MEDS scores. }\end{array}$ & $\begin{array}{l}\text { The authors } \\
\text { were limited } \\
\text { to scores that } \\
\text { were already } \\
\text { entered in an } \\
\text { existing } \\
\text { registry over } \\
6 \text { years. } \\
\text { The authors } \\
\text { accepted the } \\
\text { existing } \\
\text { literature that } \\
\text { there would } \\
\text { be inter- and } \\
\text { intra- } \\
\text { observer } \\
\text { variability in } \\
\text { computing } \\
\text { the scores and } \\
\text { that such } \\
\text { variability } \\
\text { may lead to } \\
\text { misclassificat } \\
\text { ion of a } \\
\text { patient's } \\
\text { severity. } \\
\text { The authors } \\
\text { found some } \\
\text { limitations to } \\
\text { the APACHE } \\
\text { II score, } \\
\text { which could } \\
\text { give variable } \\
\text { results. }\end{array}$ & $\begin{array}{l}\text { II-2 } \\
1 \mathrm{C}\end{array}$ \\
\hline
\end{tabular}




\begin{tabular}{|c|c|c|c|c|c|c|}
\hline Year & $\begin{array}{c}\text { Author } \\
\text { Title } \\
\text { Journal }\end{array}$ & Purpose & Design/Sample & $\begin{array}{c}\text { Results/ } \\
\text { Recommendations }\end{array}$ & Limitations & $\begin{array}{l}\text { Level/ } \\
\text { Grade }\end{array}$ \\
\hline & $\begin{array}{l}\text { Journal of } \\
\text { Critical Care }\end{array}$ & & & & & \\
\hline 2014 & $\begin{array}{l}\text { Patocka, C., } \\
\text { Turner, J., } \\
\text { Xue, X., \& } \\
\text { Segal, E. } \\
\text { Evaluation of } \\
\text { an } \\
\text { emergency } \\
\text { department } \\
\text { triage } \\
\text { screening } \\
\text { tool for } \\
\text { suspected } \\
\text { severe sepsis } \\
\text { and septic } \\
\text { shock. } \\
\text { Journal for } \\
\text { Healthcare } \\
\text { Quality }\end{array}$ & $\begin{array}{l}\text { To determine } \\
\text { the effect of a } \\
\text { triage } \\
\text { screening tool } \\
\text { on time to } \\
\text { antibiotics in } \\
\text { patients with } \\
\text { severe sepsis } \\
\text { or septic } \\
\text { shock } \\
\text { presenting to } \\
\text { the ED. }\end{array}$ & $\begin{array}{l}\text { Retrospective } \\
\text { pre/post chart } \\
\text { review }\end{array}$ & $\begin{array}{l}\text { After } \\
\text { implementation of } \\
\text { the triage } \\
\text { assessment tool, } \\
\text { mean time to } \\
\text { antibiotics } \\
\text { decreased by } 21 \% \text {. } \\
\text { Sixty-four percent } \\
\text { of the patients who } \\
\text { qualified for the } \\
\text { study were } \\
\text { appropriately } \\
\text { identified and had } \\
\text { the triage sheet } \\
\text { filled out } \\
\text { appropriately post- } \\
\text { implementation. } \\
\text { Despite only } \\
\text { moderate adherence } \\
\text { (64\%), the } \\
\text { implementation of a } \\
\text { sepsis screening } \\
\text { tool at triage } \\
\text { appears to have } \\
\text { significantly } \\
\text { decreased the time } \\
\text { from triage to } \\
\text { antibiotic } \\
\text { administration in } \\
\text { patients presenting } \\
\text { with suspected } \\
\text { severe sepsis or } \\
\text { septic shock. }\end{array}$ & $\begin{array}{l}\text { The pre/post } \\
\text { chart review } \\
\text { has a } \\
\text { potential for } \\
\text { bias and } \\
\text { unrecorded } \\
\text { cofounders. } \\
\text { The } \\
\text { retrospective } \\
\text { nature of the } \\
\text { study design } \\
\text { makes it } \\
\text { difficult to } \\
\text { establish } \\
\text { casualty } \\
\text { between the } \\
\text { results } \\
\text { obtained and } \\
\text { the } \\
\text { implementati } \\
\text { on of the } \\
\text { sepsis } \\
\text { protocol. } \\
\text { The authors' } \\
\text { definitions of } \\
\text { suspected } \\
\text { severe sepsis } \\
\text { and septic } \\
\text { shock could } \\
\text { be } \\
\text { questioned, } \\
\text { especially } \\
\text { since in their } \\
\text { criteria, they } \\
\text { did not } \\
\text { specify how } \\
\text { the } \\
\text { temperature } \\
\text { of the patient } \\
\text { should be } \\
\text { measured. } \\
\text { Some, but not } \\
\text { all were } \\
\text { measured } \\
\text { orally. }\end{array}$ & $\begin{array}{l}\text { II-3 } \\
2 \mathrm{~A}\end{array}$ \\
\hline 2014 & $\begin{array}{l}\text { Puskarich, } \\
\text { M. A., Illich, } \\
\text { B. M., \& } \\
\text { Jones, A. E. } \\
\text { Prognosis of } \\
\text { emergency } \\
\text { department } \\
\text { patients with } \\
\text { suspected }\end{array}$ & $\begin{array}{l}\text { To quantify } \\
\text { the prognostic } \\
\text { significance } \\
\text { of } \\
\text { intermediate } \\
\text { blood lactate } \\
\text { levels in ED } \\
\text { patients with } \\
\text { suspected } \\
\text { infection, }\end{array}$ & $\begin{array}{l}\text { Systematic } \\
\text { review }\end{array}$ & $\begin{array}{l}8 \text { studies were } \\
\text { included. } \\
\text { Among ED patients } \\
\text { with suspected } \\
\text { infection, } \\
\text { intermediate lactate } \\
\text { elevation is } \\
\text { associated with a } \\
\text { moderate to high }\end{array}$ & $\begin{array}{l}\text { Conference } \\
\text { abstracts and } \\
\text { other } \\
\text { unpublished } \\
\text { data from the } \\
\text { "gray" } \\
\text { literature } \\
\text { were not } \\
\text { identified. }\end{array}$ & $\begin{array}{l}\mathrm{I} \\
1 \mathrm{~B}\end{array}$ \\
\hline
\end{tabular}




\begin{tabular}{|c|c|c|c|c|c|c|}
\hline Year & $\begin{array}{c}\text { Author } \\
\text { Title } \\
\text { Journal }\end{array}$ & Purpose & Design/Sample & $\begin{array}{c}\text { Results/ } \\
\text { Recommendations }\end{array}$ & Limitations & $\begin{array}{l}\text { Level/ } \\
\text { Grade }\end{array}$ \\
\hline & $\begin{array}{l}\text { infection and } \\
\text { intermediate } \\
\text { lactate } \\
\text { levels: A } \\
\text { systematic } \\
\text { review. } \\
\text { Journal of } \\
\text { Critical Care }\end{array}$ & $\begin{array}{l}\text { emphasizing } \\
\text { patients } \\
\text { without } \\
\text { hypotension. }\end{array}$ & & $\begin{array}{l}\text { risk of mortality, } \\
\text { even among } \\
\text { patients without } \\
\text { hypotension. } \\
\text { Physicians should } \\
\text { be aware of the } \\
\text { poor prognosis of } \\
\text { this group of } \\
\text { patients, should } \\
\text { monitor them } \\
\text { closely, and give } \\
\text { more consideration } \\
\text { to more aggressive } \\
\text { treatment to prevent } \\
\text { further progression } \\
\text { to shock or death. }\end{array}$ & & \\
\hline 2014 & $\begin{array}{l}\text { Schaub, N., } \\
\text { Boldanova, } \\
\text { T., Noveanu, } \\
\text { M., Arenja, } \\
\text { N., } \\
\text { Hermann, } \\
\text { H., } \\
\text { Twerenbold, } \\
\text { R., ... } \\
\text { Mueller, C. } \\
\text { Incremental } \\
\text { value of } \\
\text { multiplex } \\
\text { real-time } \\
\text { PCR for the } \\
\text { early } \\
\text { diagnosis of } \\
\text { sepsis in the } \\
\text { emergency } \\
\text { department. } \\
\text { Swiss } \\
\text { Medical } \\
\text { Weekly }\end{array}$ & $\begin{array}{l}\text { To assess the } \\
\text { diagnostic } \\
\text { accuracy of } \\
\text { blood cultures } \\
\text { and PCR in } \\
\text { adult patients } \\
\text { presenting to } \\
\text { the ED with } \\
\text { suspected } \\
\text { sepsis. }\end{array}$ & Cohort study & $\begin{array}{l}\text { The diagnostic } \\
\text { accuracy of PCR in } \\
\text { detecting sepsis and } \\
\text { its causative } \\
\text { organism was } \\
\text { comparable to that } \\
\text { of blood cultures. } \\
\text { The additional use } \\
\text { of PCR } \\
\text { significantly } \\
\text { reduced time to } \\
\text { microbiological } \\
\text { diagnosis as } \\
\text { compared to the use } \\
\text { of conventional use } \\
\text { of microbiological } \\
\text { methods alone. } \\
\text { PCR does not offer } \\
\text { broad susceptibility } \\
\text { testing, and can } \\
\text { only be used as an } \\
\text { adjunct method to } \\
\text { blood cultures at } \\
\text { this time. }\end{array}$ & $\begin{array}{l}\text { PCR may } \\
\text { potentially } \\
\text { lead to } \\
\text { detection of } \\
\text { bacteremia } \\
\text { and } \\
\text { fungaemia } \\
\text { due to } \\
\text { translocation } \\
\text { from } \\
\text { naturally } \\
\text { colonizes } \\
\text { surfaces and } \\
\text { even non- } \\
\text { replicating } \\
\text { bacteria. } \\
\text { The cohort } \\
\text { was very } \\
\text { small, with } \\
110 \text { patients; } \\
79 \text { with sepsis } \\
\text { and only } 36 \\
\text { with positive } \\
\text { cultures. }\end{array}$ & $\begin{array}{l}\mathrm{II}-2 \\
1 \mathrm{C}\end{array}$ \\
\hline 2013 & $\begin{array}{l}\text { Tipler, P. S., } \\
\text { Pamplin, J., } \\
\text { Mysliwiec, } \\
\text { V., } \\
\text { Anderson, } \\
\text { A., \& Mount, } \\
\text { C. A. } \\
\text { Use of a } \\
\text { protocolized } \\
\text { approach to } \\
\text { the } \\
\text { management } \\
\text { of sepsis can } \\
\text { improve time } \\
\text { to first dose }\end{array}$ & $\begin{array}{l}\text { To determine } \\
\text { if a sepsis } \\
\text { protocol } \\
\text { improved the } \\
\text { time to first } \\
\text { dose of } \\
\text { antibiotics in } \\
\text { patients } \\
\text { diagnosed } \\
\text { with sepsis. }\end{array}$ & $\begin{array}{l}\text { Retrospective } \\
\text { chart review }\end{array}$ & $\begin{array}{l}\text { The average time to } \\
\text { first dose of } \\
\text { antibiotics for the } \\
\text { presepsis protocol } \\
\text { group was } 160 \\
\text { minutes, and for the } \\
\text { sepsis protocol } \\
\text { group was } 99 \\
\text { minutes. } \\
\text { Initiation of a sepsis } \\
\text { protocol, which } \\
\text { emphasizes early } \\
\text { goal-directed } \\
\text { therapy, can } \\
\text { improve time to }\end{array}$ & $\begin{array}{l}\text { Limitations } \\
\text { inherent to a } \\
\text { retrospective } \\
\text { examination } \\
\text { of various } \\
\text { data are } \\
\text { present. } \\
\text { The study } \\
\text { was not } \\
\text { designed in a } \\
\text { manner that } \\
\text { allowed for } \\
\text { detecting a } \\
\text { difference in } \\
\text { outcomes of }\end{array}$ & $\begin{array}{l}\text { II-3 } \\
1 \mathrm{C}\end{array}$ \\
\hline
\end{tabular}




\begin{tabular}{|c|c|c|c|c|c|c|}
\hline Year & $\begin{array}{c}\text { Author } \\
\text { Title } \\
\text { Journal }\end{array}$ & Purpose & Design/Sample & $\begin{array}{c}\text { Results/ } \\
\text { Recommendations }\end{array}$ & Limitations & $\begin{array}{l}\text { Level/ } \\
\text { Grade }\end{array}$ \\
\hline & $\begin{array}{l}\text { of } \\
\text { antibiotics. } \\
\text { Journal of } \\
\text { Critical Care }\end{array}$ & & & $\begin{array}{l}\text { administration of } \\
\text { first dose of } \\
\text { antibiotics. }\end{array}$ & $\begin{array}{l}\text { patients } \\
\text { treated for } \\
\text { sepsis before } \\
\text { and after the } \\
\text { protocol was } \\
\text { initiated. }\end{array}$ & \\
\hline 2010 & $\begin{array}{l}\text { Tromp, M., } \\
\text { Hulscher, } \\
\text { M., Bleeker- } \\
\text { Rovers, C. } \\
\text { P., Peters, L., } \\
\text { van den } \\
\text { Berg, D. T., } \\
\text { Borm, G. F., } \\
\text {.. Pickkers, } \\
\text { P. } \\
\text { The role of } \\
\text { nurses in the } \\
\text { recognition } \\
\text { and } \\
\text { treatment of } \\
\text { patients with } \\
\text { sepsis in the } \\
\text { emergency } \\
\text { department: } \\
\text { A } \\
\text { prospective } \\
\text { before-and- } \\
\text { after } \\
\text { intervention } \\
\text { study. } \\
\text { International } \\
\text { Journal of } \\
\text { Nursing } \\
\text { Studies }\end{array}$ & $\begin{array}{l}\text { To determine } \\
\text { the effects of } \\
\text { a multifaceted } \\
\text { implementatio } \\
\text { n program } \\
\text { including the } \\
\text { introduction } \\
\text { of a nurse- } \\
\text { driven, care- } \\
\text { bundle based, } \\
\text { sepsis } \\
\text { protocol } \\
\text { followed by } \\
\text { training and } \\
\text { performance } \\
\text { feedback. }\end{array}$ & $\begin{array}{l}\text { Prospective } \\
\text { before-and-after } \\
\text { intervention } \\
\text { study }\end{array}$ & $\begin{array}{l}\text { Compliance with } \\
\text { the complete bundle } \\
\text { significantly } \\
\text { improved from } \\
3.5 \% \text { at baseline to } \\
12.4 \% \text { after the } \\
\text { implementation } \\
\text { program was put } \\
\text { into place. } \\
\text { The mean number } \\
\text { of performed } \\
\text { bundle elements } \\
\text { improved } \\
\text { significantly from } \\
\text { 3.0 elements at } \\
\text { baseline to } 4.2 \\
\text { elements after } \\
\text { intervention. } \\
\text { Using a nurse- } \\
\text { driven, care bundle } \\
\text { based, sepsis } \\
\text { protocol followed } \\
\text { by training and } \\
\text { performance } \\
\text { feedback results in } \\
\text { improved early } \\
\text { recognition and } \\
\text { treatment of } \\
\text { patients with sepsis } \\
\text { who present to the } \\
\text { ED. } \\
\text { More attention } \\
\text { should be given to } \\
\text { the role of nurses in } \\
\text { quality of } \\
\text { improvement of } \\
\text { sepsis care. }\end{array}$ & $\begin{array}{l}\text { Was an } \\
\text { uncontrolled } \\
\text { study in a } \\
\text { single center. } \\
\text { Results } \\
\text { cannot be } \\
\text { extrapolated } \\
\text { since the } \\
\text { program was } \\
\text { tailor-made to } \\
\text { the situation } \\
\text { of the } \\
\text { hospital. } \\
\text { The clinical } \\
\text { signs } \\
\text { included in } \\
\text { the sepsis } \\
\text { screening list } \\
\text { are very } \\
\text { sensitive, but } \\
\text { not very } \\
\text { specific. }\end{array}$ & $\begin{array}{l}\text { II-3 } \\
1 \mathrm{C}\end{array}$ \\
\hline 2013 & $\begin{array}{l}\text { Turi, S. K., } \\
\text { \& Von Ah, } \\
\text { D } \\
\text { Implementati } \\
\text { on of early } \\
\text { goal-directed } \\
\text { therapy for } \\
\text { septic } \\
\text { patients in } \\
\text { the } \\
\text { emergency } \\
\text { department: }\end{array}$ & $\begin{array}{l}\text { To review the } \\
\text { literature } \\
\text { regarding the } \\
\text { implementatio } \\
\mathrm{n} \text { of the sepsis } \\
\text { guidelines in } \\
\text { emergency } \\
\text { departments. }\end{array}$ & Systemic review & $\begin{array}{l}\text { Studies that } \\
\text { discussed } \\
\text { collaboration, } \\
\text { preplanning, and } \\
\text { education were able } \\
\text { to implement } \\
\text { monitoring of } \\
\text { central venous } \\
\text { pressure, mean } \\
\text { arterial pressure, } \\
\text { and central venous } \\
\text { oxygen saturation. }\end{array}$ & $\begin{array}{l}\text { Studies } \\
\text { reviewed } \\
\text { were limited } \\
\text { by their } \\
\text { design, } \\
\text { setting/sampl } \\
\text { e, and length } \\
\text { of follow-up. } \\
\text { No RCTs or } \\
\text { meta-analysis } \\
\text { were } \\
\text { identified in }\end{array}$ & $\begin{array}{l}\mathrm{I} \\
1 \mathrm{C}\end{array}$ \\
\hline
\end{tabular}




\begin{tabular}{|c|c|c|c|c|c|c|}
\hline Year & $\begin{array}{c}\text { Author } \\
\text { Title } \\
\text { Journal }\end{array}$ & Purpose & Design/Sample & $\begin{array}{c}\text { Results/ } \\
\text { Recommendations }\end{array}$ & Limitations & $\begin{array}{l}\text { Level/ } \\
\text { Grade }\end{array}$ \\
\hline & $\begin{array}{l}\text { A review of } \\
\text { the literature. } \\
\text { Journal of } \\
\text { Emergency } \\
\text { Nursing }\end{array}$ & & & $\begin{array}{l}\text { Nursing } \\
\text { interventions } \\
\text { recommended by } \\
\text { the Surviving } \\
\text { Sepsis Campaign } \\
\text { such as measuring } \\
\text { urine output and } \\
\text { obtaining blood } \\
\text { cultures were less } \\
\text { often considered. } \\
\text { More research is } \\
\text { needed to overcome } \\
\text { barriers to } \\
\text { implementing early } \\
\text { goal-directed } \\
\text { therapy and to } \\
\text { uncover which } \\
\text { elements are most } \\
\text { important and } \\
\text { feasible to achieve } \\
\text { optimal patient } \\
\text { outcomes. }\end{array}$ & $\begin{array}{l}\text { the search. } \\
\text { All studies } \\
\text { were in single } \\
\text { EDs. } \\
\text { Studies } \\
\text { reviewed had } \\
\text { lack of } \\
\text { discussion as } \\
\text { to how to } \\
\text { keep and } \\
\text { maintain the } \\
\text { momentum of } \\
\text { using the } \\
\text { sepsis } \\
\text { guidelines } \\
\text { after an initial } \\
\text { implementati } \\
\text { on. }\end{array}$ & \\
\hline 2013 & $\begin{array}{l}\text { Zhao, Y., Li, } \\
\text { C., \& Jia, Y. } \\
\text { Evaluation of } \\
\text { the Mortality } \\
\text { in } \\
\text { Emergency } \\
\text { Sepsis score } \\
\text { combined } \\
\text { with } \\
\text { procalcitonin } \\
\text { in septic } \\
\text { patients. } \\
\text { American } \\
\text { Journal of } \\
\text { Emergency } \\
\text { Medicine }\end{array}$ & $\begin{array}{l}\text { To determine } \\
\text { an effective } \\
\text { method for } \\
\text { predicting } \\
\text { severity of } \\
\text { sepsis and 28- } \\
\text { day mortality } \\
\text { of ED } \\
\text { patients, } \\
\text { comparing the } \\
\text { MEDS score } \\
\text { with } \\
\text { procalcitonin, } \\
\text { interleukin-6 } \\
\text { (IL-6), and C- } \\
\text { Reactive } \\
\text { protein } \\
\text { (CRP), and to } \\
\text { evaluate the } \\
\text { MEDS score } \\
\text { combined } \\
\text { with relevant } \\
\text { biomarkers. }\end{array}$ & $\begin{array}{l}\text { Prospective } \\
\text { study }\end{array}$ & $\begin{array}{l}\text { The new } \\
\text { combination of the } \\
\text { MEDS score with } \\
\text { PCT improved the } \\
\text { area under the curve } \\
\text { for severity and } \\
\text { mortality. } \\
\text { This new } \\
\text { combination had } \\
\text { better sensitivity, } \\
\text { specificity, and } \\
\text { positive predicative } \\
\text { and negative } \\
\text { predicative values. } \\
\text { The predictive } \\
\text { ability of the MEDS } \\
\text { score for severity } \\
\text { and } 28 \text {-day } \\
\text { mortality of septic } \\
\text { ED patients is better } \\
\text { than the PCT, IL-6, } \\
\text { and CRP levels. } \\
\text { The MEDS score } \\
\text { combined with PCT } \\
\text { enhances the ability } \\
\text { of risk stratification } \\
\text { and prognostic } \\
\text { evaluation. }\end{array}$ & $\begin{array}{l}\text { PCT, IL-6, } \\
\text { and CRP } \\
\text { rises, peaks, } \\
\text { and plateaus } \\
\text { were different } \\
\text { among } \\
\text { biomarkers. } \\
\text { Only } 1 \\
\text { biomarker } \\
\text { concentration } \\
\text { was obtained } \\
\text { at the time of } \\
\text { ED } \\
\text { evaluation } \\
\text { instead of at } \\
\text { serial time } \\
\text { points. } \\
\text { All patients in } \\
\text { the study } \\
\text { were } \\
\text { nonoperative } \\
\text { septic } \\
\text { patients from } \\
\text { the ED } \\
\text { resuscitation } \\
\text { room, not all } \\
\text { ED sepsis } \\
\text { patients } \\
\text { which limited } \\
\text { the sample } \\
\text { size. }\end{array}$ & $\begin{array}{l}\text { II-2 } \\
2 \mathrm{~A}\end{array}$ \\
\hline
\end{tabular}

Note: Levels modified from:

DiCenso, Guyatt, \& Ciliska and the Canadian Task Force on Preventive Health Care Levels of Evidence and Grades of Recommendations (p 519) 
Grades derived from: DiCenso, Guyatt, \& Ciliska (p 166)

\section{APPENDIX B}

Levels of Evidence Modified from DiCenso, Guyatt, \& Ciliska and the Canadian Task Force on Preventive Health Care Levels of Evidence (p 519)

\begin{tabular}{|l|l|}
\hline Level & Explanation \\
\hline I & Evidence from at least one well-designed randomized controlled trial \\
\hline II-1 & Evidence from well-designed controlled trials without randomization \\
\hline II-2 & $\begin{array}{l}\text { Evidence from well-designed cohort or case-control analytic studies, preferably from more than one } \\
\text { center or research group }\end{array}$ \\
\hline II-3 & $\begin{array}{l}\text { Evidence from comparisons between times or places with or without the intervention: results from } \\
\text { uncontrolled studies could be included here }\end{array}$ \\
\hline III & $\begin{array}{l}\text { Opinions of respected authorities, based on clinical experience; descriptive studies or reports of } \\
\text { expert committees }\end{array}$ \\
\hline
\end{tabular}

\section{APPENDIX C}

Grades of Evidence Derived from: DiCenso, Guyatt, \& Ciliska (p 166)

\begin{tabular}{|c|c|c|c|}
\hline \begin{tabular}{|l} 
Grade \\
Recommendation
\end{tabular} & $\begin{array}{l}\text { of Balance Between Benefits } \\
\text { and }\end{array}$ & $\begin{array}{l}\text { Methodological Strength } \\
\text { of }\end{array}$ & Implications \\
\hline & Risks & Supporting Evidence in & \\
\hline & & Systematic Reviews & \\
\hline \multirow[t]{4}{*}{$1 \mathrm{~A}$} & Clear & RCTs without important & $\begin{array}{l}\text { Strong recommendation; } \\
\text { can }\end{array}$ \\
\hline & & limitations & $\begin{array}{l}\text { apply to most patients in } \\
\text { most }\end{array}$ \\
\hline & & & circumstances without \\
\hline & & & reservation \\
\hline \multirow[t]{3}{*}{$1 \mathrm{~B}$} & Clear & RCTs with important & $\begin{array}{l}\text { Strong recommendation; } \\
\text { likely }\end{array}$ \\
\hline & & $\begin{array}{l}\text { limitations (inconsistent } \\
\text { results, }\end{array}$ & to apply to most patients in \\
\hline & & methodological flaws) & most circumstances \\
\hline \multirow[t]{6}{*}{$1 \mathrm{C}+$} & Clear & $\begin{array}{l}\text { No RCTs directly } \\
\text { addressing }\end{array}$ & $\begin{array}{l}\begin{array}{l}\text { Strong recommendation; } \\
\text { can }\end{array} \\
\end{array}$ \\
\hline & & $\begin{array}{l}\text { the question, but results } \\
\text { from }\end{array}$ & $\begin{array}{l}\text { apply to most patients in } \\
\text { most }\end{array}$ \\
\hline & & closely related RCTs can be & circumstances \\
\hline & & $\begin{array}{l}\text { unequivocally extrapolated, } \\
\text { or }\end{array}$ & \\
\hline & & $\begin{array}{|lc|}\begin{array}{l}\text { evidence } \\
\text { observational }\end{array} & \text { from } \\
\end{array}$ & \\
\hline & & \begin{tabular}{ll|} 
studies may be berwhelming &
\end{tabular} & \\
\hline \multirow[t]{4}{*}{$1 \mathrm{C}$} & Clear & Observational studies & Intermediate-strength \\
\hline & & & $\begin{array}{l}\text { recommendation; may } \\
\text { change }\end{array}$ \\
\hline & & & when stronger evidence is \\
\hline & & & available \\
\hline \multirow[t]{5}{*}{$2 \mathrm{~A}$} & Unclear & RCTs without important & Intermediate-strength \\
\hline & & limitations & $\begin{array}{l}\text { recommendation; best } \\
\text { action }\end{array}$ \\
\hline & & & may differ depending on \\
\hline & & & circumstances or patient or \\
\hline & & & societal values \\
\hline \multirow[t]{4}{*}{$2 \mathrm{~B}$} & Unclear & RCTs with important & Weak recommendation; \\
\hline & & $\begin{array}{l}\text { limitations(inconsistent } \\
\text { results, }\end{array}$ & \begin{tabular}{|l|} 
alternative approaches \\
likely to
\end{tabular} \\
\hline & & methodological flaws) & be better for some patients \\
\hline & & & under some circumstances \\
\hline $2 \mathrm{C}$ & Unclear & Observational studies & Very weak \\
\hline
\end{tabular}




\begin{tabular}{|l|l|l|l|}
\hline & & & recommendation; \\
\hline & & & other alternatives may be \\
\hline & & & equally reasonable \\
\hline
\end{tabular}

\section{APPENDIX D}

\section{Evaluation for Severe Sepsis Screening Tool}

Instructions: Use this optional tool to screen patients for severe sepsis in the emergency department, on the medical/surgical floors, or in the ICU.

\section{Is the patient's history suggestive of a new infection?}

Pneumonia, empyema

Urinary tract infection

Acute abdominal infection

Meningitis

Skin/soft tissue infection

\author{
Bone/joint infection \\ Wound infection \\ Implantable device infection \\ Other infection
}

Blood stream catheter

infection

Endocarditis

\section{__ Yes _}

2. Are any two of following signs \& symptoms of infection both present and new to the patient? Note: laboratory values may have been obtained for inpatients but may not be available for outpatients.

Hyperthermia $>38.3^{\circ} \mathrm{C}\left(101.0^{\circ} \mathrm{F}\right)$

Hypothermia $36^{\circ} \mathrm{C}\left(96.8^{\circ} \mathrm{F}\right)$

Altered mental status Tachycardia $>90$ bpm
Tachypnea $>20 \mathrm{bpm}$

Leukocytosis (WBC count $>12,000 \mu \mathrm{L}-1)$

Leukopenia (WBC count $<4000 \mu \mathrm{L}-1$ )

Hyperglycemia (plasma glucose $>140 \mathrm{mg} / \mathrm{dL}$ ) or

$7.7 \mathrm{mmol} / \mathrm{L}$ in the absence of diabetes Yes No

If the answer is yes, to both questions 1 and 2, suspicion of infection is present:

Ask physician about obtaining: lactic acid, blood cultures,

At the physician's discretion obtain: CBC with differential, basic chemistry labs, bilirubin, UA, chest x-ray, amylase, lipase, ABG, CRP, CT scan.

3. Are any of the following organ dysfunction criteria present at a site remote from the site of the infection that are NOT considered to be chronic conditions? Note: in the case of bilateral pulmonary infiltrates the remote site stipulation is waived.

SBP $<90 \mathrm{mmHg}$ or $\mathrm{MAP}<65 \mathrm{mmHg}$

SBP decrease $>40 \mathrm{~mm} \mathrm{Hg}$ from baseline

Creatinine $>2.0 \mathrm{mg} / \mathrm{dl}(176.8 \mathrm{mmol} / \mathrm{L})$ or urine

output $<0.5 \mathrm{ml} / \mathrm{kg} /$ hour for 2 hours Bilirubin $>2 \mathrm{mg} / \mathrm{dl}(34.2 \mathrm{mmol} / \mathrm{L})$

Platelet count $<100,000 \mu \mathrm{L}$

Lactate $>2 \mathrm{mmol} / \mathrm{L}(18.0 \mathrm{mg} / \mathrm{dl})$

Coagulopathy (INR $>1.5$ or aPTT $>60$ secs)

Acute lung injury with $\mathrm{PaO} 2 / \mathrm{FiO} 2<250$ in the absence of pneumonia as infection source

Acute lung injury with $\mathrm{PaO} 2 / \mathrm{FiO} 2<200$ in the presence of pneumonia as infection source

_ Yes _ No

If suspicion of infection and yes or no to severe organ dysfunction criteria, ask physician about starting a broad-spectrum antibiotic

\section{APPENDIX E}

$\underline{\text { Severe Sepsis Chart Review data collection tool for educational purposes }}$

\section{Based on the Evaluation for Severe Sepsis Screening Tool}


Does the patient history suggest a new infection? If yes,

Does the patient present with two or more new signs or symptoms of infection? If yes,

Does the patient have evidence of organ dysfunction due to the infection?

1. Met Criteria for

Severe Sepsis

2. Determine the date and time of presentation

- Time of presentation is equal to ED triage time or documentation (date and time) supporting the diagnosis of severe sepsis in the progress notes for non-ED admissions.

3. Admission Category:

ED $\square$ Transferred to Critical Care Unit from unit other than ED $\quad$ Currently in the ICU

Patients on the floor/unit outside the ED, enter date and time of last sepsis screen

Hospital Admission Critical Care Unit admission

Check if completed, proceed to enter date, time, and Y/N as appropriate $\mathrm{mmol} / \mathrm{L} \mathrm{mg/dl}$ No

5. Obtain blood cultures prior to antibiotic administration __ Yes ___ _ _ _ _ _ _

Collected before the patient was started on an antibiotic for a suspected infection other than severe sepsis and continued until the time of presentation

6. Administer broad-spectrum antibiotic,

1. 1

A broad spectrum antibiotic was initiated for a suspected infection other than severe sepsis and continued until the time of presentation with severe sepsis Hospital Discharge ____________________ Status ${ }^{\square}$ Alive Deceased 


\section{APPENDIX F}

Process Flow Map
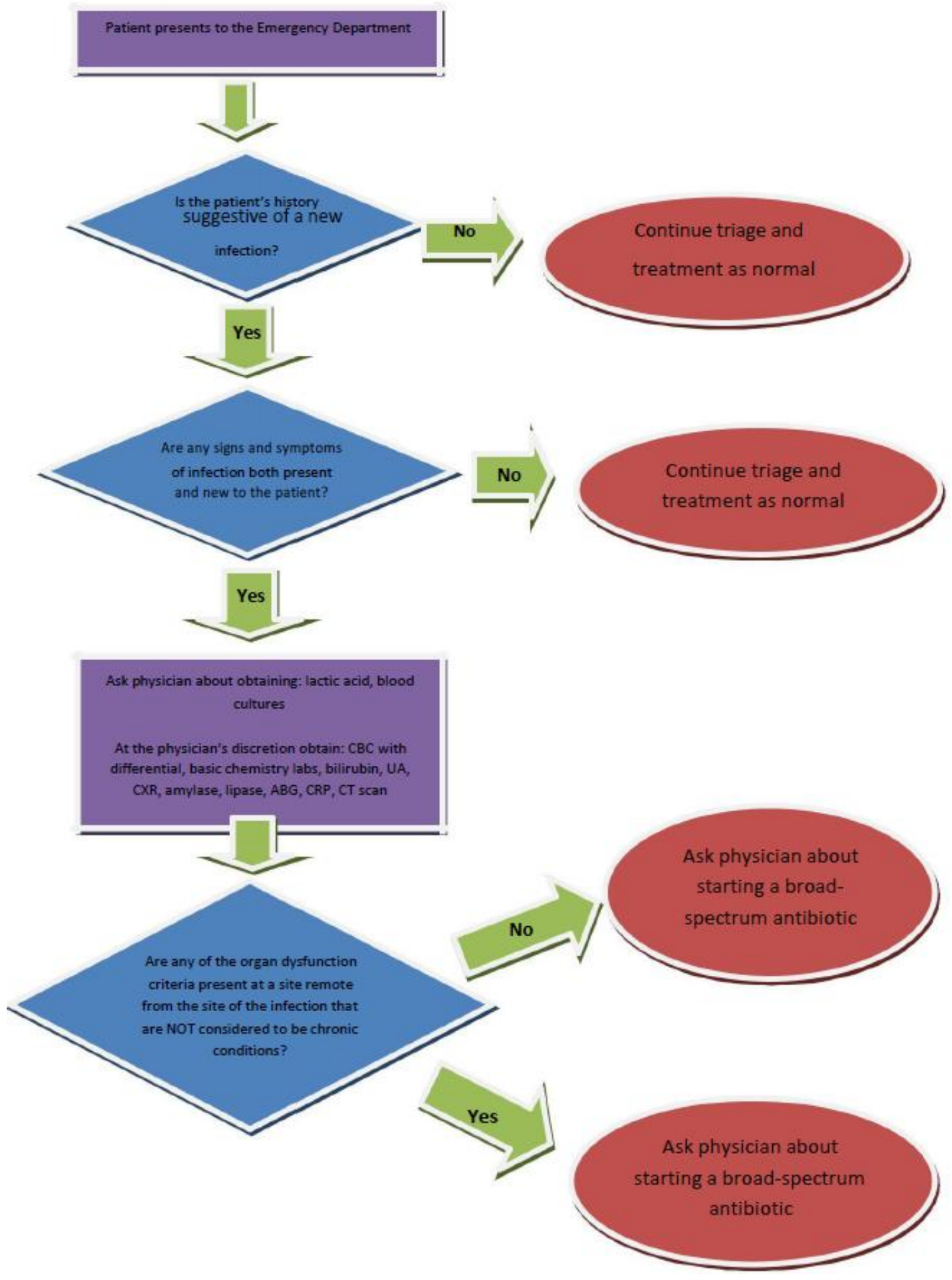

\section{APPENDIX G}

Patient Information Sheet

\section{Early Recognition of Sepsis in the Emergency Department Nycole Oliver, BSN, RN, CEN, DNPc} ndo1102@jagmail.southalabama.edu

You arrived in to the Emergency Department (ED) with suspected signs and symptoms of sepsis. A study is being conducted to increase early recognition of sepsis, which is a systemic inflammatory response system typically triggered by an infection, and is associated with many other illnesses. 
Sepsis accounts for over a half million ED visits each year. One of the biggest advancements in sepsis treatment has been promotion of early goal-directed therapy (EGDT), a key component of which is early recognition in the ED.

The purpose of the study is to increase early recognition of sepsis in the Emergency Department. A screening tool is being utilized that will assist with early recognition of sepsis as soon as a patient arrives in the Emergency Department. The data collected from this screening tool will be used to determine the length of time between arrival, the diagnosis of sepsis and the start of treatment. The goal of this study is to ensure that all patients who have the diagnosis of sepsis will receive the start of treatment within three hours.

The information about your diagnosis will remain anonymous and no identifying data will be collected. All data will be kept for 5 years after completion of the project; and then shredded.

The data collected is anonymous and cannot be linked to you in any way. The benefit of collecting this information may assist the Emergency Department in developing new screening methods.

Please contact me at ndo1102@jagmail.southalabama.edu, the Institutional Review Board at the University of South Alabama at (251) 460-6308, or the Institutional Review Board at Sparks Regional Medical Center at (479) 441-5345 if you have additional questions.

Citation: Nycole D. Oliver. Early Recognition of Sepsis in the Emergency Department, ARC Journal of Nursing and Healthcare. 2018; 4(1): 3-20. doi: dx.doi.org/ 10.20431/2455-4324.0401002.

Copyright: (C) 2018 Authors. This is an open-access article distributed under the terms of the Creative Commons Attribution License, which permits unrestricted use, distribution, and reproduction in any medium, provided the original author and source are credited. 